\title{
THE IMPACT OF FOREIGN DIRECT INVESTMENT ON STOCK MARKET DEVELOPMENT: EVIDENCE FROM PAKISTAN
}

\author{
Muhammad Shahbaza , Hooi Hooi Lean ${ }^{\mathrm{b}}$, Rukhsana Kalim ${ }^{c}$ \\ ${ }^{a}$ Department of Management Sciences, COMSATS Institute of Information Technology. \\ ${ }^{b}$ Economics Program, School of Social Sciences, Universiti Sains Malaysia. \\ 'Department Economics, University of Management and Technology
}

\section{ARTICLE INFO \\ Article data: \\ - Received: 14 November 2011 \\ - Accepted: 10 April 2012}

JEL classification: G24, N25, C50

Keywords:

- Stock Market development

- Foreign Direct Investment

- Pakistan

- Complementary

- Cointegration

\begin{abstract}
Developing countries are witnessing changes in the composition of capital flows in their economies due to the expansion and integration of the world equity market. This paper investigates the impact of foreign direct investment on the stock market development in Pakistan. The key interest revolves around the complementary or substitution role of foreign direct investment to the development of stock market. ARDL bounds testing approach to cointegrationand ECM are employed for the analysis. Our results support the complementary role of foreign direct investment to the stock market development in Pakistan. Moreover, domestic savings, income and inflation are the other macroeconomic variables that affect the development of stock market in Pakistan.
\end{abstract}

Reference to this paper should be made as follows: Shahbaz, M; Lean. H;Kalim,R;. 2013. The impact of foreign direct investment on stock market development: Evidence from Pakistan, Ekonomska istraživanja - Economic Research 26(1): 17-32. 


\section{INTRODUCTION}

A strong financial system guarantees the economic growth and stability of a country. As an important catalyst, capital market plays a vital role in generating long term financial resources and channeling them into productive investments. Hence, efficient capital market is essential for economic growth and prosperity. In between, stock market is an integral part of the financial system of an economy. It is a source of financing new venture based on its expected profitability. Stock market is the replica of economic strength of a country. To boost investment, savings and economic growth; the development of stock market is imperative and cannot be ignored in any economy. The development of stock market is the outcome of many factors such as exchange rate, political stability, foreign direct investment (FDI) and economic liberalization. Theoretical works show positive impact of stock market development on economic growth (e.g. DemirgucKunt and Levine 1996; Sing, 1997; and Levine and Zervos, 1998).

In the era of globalization, FDI is a major source of capital in most of the developing countries where it bridges the gap of capital, technology, managerial skill, human capital formation and more competitive business environment. However, the role of FDI in economic development is found mixed in the economic literature. On one hand, FDI transfers business know-how and technology to the host country (Romer, 1993). On the other hand, the presence of pre-existing trade, price, financial, and other distortions will hurt resources allocation and hence sluggishthe economic growth (Brecher and Diaz-Alejandro, 1977; Brecher, 1983; Boyd and Smith, 1999). Carkovic and Levine (2002) showed that FDI does not exert any independent influence on economic growth. Johnson (2005) argued that FDI brings a positive effect to developing countries but not to the developed economies. Rehman and Salahuddin (2009) also suggested that FDI will only promote economic growth under certain policy conditions. Hence, empirical evidences produce ambiguous prediction about the effect of FDI.

It is observed that there is a triangle relationship between FDI, stock market development and economic growth: (1) FDI stimulates economic growth and (2) economic growth exerts positive impact on stock market development in which (3) FDI indirectly promotes the development of stock market (Adam and Tweneboah, 2009). Given this background, the aim of this study is to identify the major contributing factors to the development of stock market in Pakistan with particular emphasis on the role of FDI. The question concerned is either FDI play a complementary or a substitution role in the stock market development. Therefore, it is hypothesized that if there is a positive relationship between FDI and stock market development, FDI plays a complementary role. On the other hand, if there is a negative relationship between the two components, FDI is substituting the stock market development.

The paper as customary is divided into different sections. Section 2 provides a brief overview of the literature on the determinants of stock market development. Section 3 highlights the salient features of the stock markets in Pakistan. Section 4 outlines the methodology and explains the model and data. Section 5 discusses results. Finally, section 6 concludes with some policy implications.

\section{LITERATURE REVIEW}

Considerable researches on impact of FDI on stock market development have been done in the literature. For example, Errunza (1983) documented long term impact of foreign capital inflows on stock market development. Krkoska (2001) reported that capital formation is positively associated with FDI in the transition countries. 
Claessens, Daniela, Schmukler (2002) concluded that the global migration of funds benefited stock market development due to more funds available for corporations and more flexibility for investors. Fritz, Desai, Hines (2005) concluded that FDI and domestic investment are complements in the production process by multinational firms in the US. Sarkar (2007) showed that in majority developed and less developed countries (including France, UK and US); the stock market turnover ratio has no positive long-term relationship with gross fixed capital formation.

Chousa, Krishna, Tamazian (2008) tried to assess whether stock markets are simply known to be the mother of all speculative businesses, or whether they are importantly linked to attract firm level's FDI in the form of cross-border mergers and acquisitions activities. They found a strong positive impact of stock markets on cross border mergers and acquisitions deals and values. Yartey (2008) identified many factors such as institutional and regulatory reforms, adequate disclosure and listing requirements and fair trading practices are important to foreign investment. Apart from that, Adam and Tweneboah (2009) indicated a long-run relationship between FDI and stock market development in Ghana. They found positive impact of FDI on stock market development. Al-Halalmeh and Sayah (2010) also examined impact of FDI on stock prices in Jordan. They concluded that a 1 percent increase in FDI will raise the value of stock market share by $45-50$ percent.

In the case of Pakistan, there is no study being done on investigating the impact of FDI on stock market development in Pakistan except Raza, lqbal, Ahmed (2012). Few studies have been investigated the relationship between stock prices and some macroeconomic variables (i.e. consumption, investment, gross domestic product, index ofindustrial production). For example, Husain and Mahmood (2001) indicated one-way causation from macroeconomic variables to stock prices. Nishat and Shaheen (2004) reported that bidirectional causality exists between industrial production and stock prices.

Rashid (2008) found long-run relationship between real interest rate, consumer prices index, nominal exchange rate and stock prices. Shahbaz, Ahmad and Ali (2008) reported bidirectional causality between stock market capitalization and economic growth. Sohail and Hussain (2011) reported that inflation, GDP and exchange rate are positively linked with stock prices but money supply and three months treasury bills rate have inverse affect on stock prices. Khan and Zaman (2012) reported that gross domestic product and exchange rate raise stock prices while consumer price index declines it.

Recently, Raza, Iqbal, Ahmed (2012) reported that FDI increases stock market capitalization. The result is expected spurious because they just examined the relationship with OLS. An effort is made in this paper to investigate the relationship of some macroeconomic variables in general and FDI in particular with the stock market development in a multivariate framework.

\section{STOCK MARKET AND FDI IN PAKISTAN}

Stock market in Pakistan is classified as one of the fastest growing stock market in emerging economies. Karachi Stock Exchange (KSE) is the biggest exchange as well as a major source of capital formation in Pakistan. The local and foreign investor's confidence to the investment environment of Pakistan has boosted the stock prices in recent years. The benchmarked stock index, KSE-100 index increased from 1,521 points on June 30, 2000 to 12,130.5 points on May 30, 2008 - a rise of over 10,000 points or 700 percent (Pakistan Economic Survey, 2008). The listed capital at KSE has increased from Rs 236.4 billion in 2000 to Rs 690.1 billion in 2008. KSE is the most liquid exchange in Pakistan. By the end of July 2008, 652 companies are listed with total paid 
up capital of Rs 690.1 billion. Although the turnover of shares declined in 2007 but it showed downward trend again in 2008 (Table1). Some major sectors contributed extraordinary to the performance of the stock market in 2008. These sectors include fuel and energy, banks and financial institutions, transport and communication, and chemicals and pharmaceuticals.

TABLE 1-PROFILE OF KARACHI STOCK EXCHANGE

\begin{tabular}{lcccl}
\hline \hline & 2005 & 2006 & 2007 & 2008 \\
\hline \hline Number of Listed Companies & 659 & 658 & 658 & 652 \\
Fund Mobilized (Rs billion) & 54.0 & 41.4 & 49.7 & 49.2 \\
Listed Capital (Rs billion) & 438.5 & 496.0 & 631.1 & 690.1 \\
Turnover of Shares (Rs billion) & 88.3 & 104.7 & 68.8 & 56.9 \\
\hline \hline
\end{tabular}

Source: Pakistan Economic Survey 2008.

Lahore Stock Exchange (LSE) is the second biggest stock market in Pakistan. LSE index showed a bullish trend during the period of 2004-2008. Aggregate market capitalization increased from Rs 1995.3 billion to Rs 4129.8 billion in 2008 (Pakistan Economic Survey, 2008). The third stock market, Islamabad Stock Exchange also showed a bullish trend in its index that increased from 2432.6 in 2005 to 3536.8 in 2008 (Pakistan Economic Survey, 2008).

Several contributing factors play their role in booming the business in stock market. For example, country's economic fundamental, stability in exchange rate, high corporate earnings, recovery of outstanding/overdue loans, large scale mergers and acquisitions, and improving relationship with the neighboring countries etc. have profound effect on the activity of the stock market. Robust economic growth during 2000-2007 contributed much to the development of the stock exchange market. 
TABLE 2- NET INFLOW OF FOREIGN DIRECT INVESTMENT BY GROUP (US\$ MILLION)

\begin{tabular}{lrrrrrrr}
\hline \hline Economic Group & 2003 & 2004 & 2005 & 2006 & 2007 & \multicolumn{2}{c}{ July -March } \\
& 7.0 & 4.6 & 22.8 & 61.9 & 515.8 & 489.8 & 33.3 \\
\hline \hline 1. Food, Bev. \& Tobacco & 26.1 & 35.5 & 39.3 & 47.0 & 59.4 & 46.8 & 22.3 \\
2. Textiles & 2.3 & 2.1 & 4.3 & 5.1 & 17.4 & 15.8 & 9.6 \\
3. Sugar, Paper and pulp & 1.2 & 3.5 & 6.5 & 8.2 & 7.3 & 6.2 & 4.6 \\
4. Leather \& Rubber & & & & & & \\
5. Chemicals and & 86.9 & 16.8 & 52.1 & 72.4 & 52.5 & 31.8 & 85.3 \\
Petrochemicals & 2.2 & 70.9 & 23.7 & 31.2 & 155.2 & 98.7 & 61.7 \\
6. Petroleum refining & 1.4 & 1.1 & 0.5 & 7.1 & 23.7 & 20.5 & 22.0 \\
7. Mining and Quarrying & 186.8 & 202.4 & 193.8 & 312.7 & 545.1 & 421.9 & 465.5 \\
8. Oil and Gas Explorations & & & & & & & \\
9. Pharmaceuticals and OTC & 6.2 & 13.2 & 38.0 & 34.5 & 38.4 & 25.7 & 38.6 \\
$\quad$ products & -0.4 & 1.9 & 13.1 & 39.0 & 33.7 & 13.4 & 89.5 \\
10. Cement & 17.6 & 17.0 & 16.5 & 21.0 & 22.0 & 15.7 & 36.5 \\
11. Electronics and Other & 0.6 & 3.3 & 33.1 & 33.1 & 50.4 & 36.7 & 73.3 \\
$\quad$ machinery & 32.8 & -14.2 & 73.3 & 320.6 & 204.6 & 125.1 & 39.8 \\
12. Transport Equipment & 17.6 & 32.0 & 42.7 & 89.5 & 157.1 & 114.4 & 69.7 \\
13. Power & 39.1 & 35.6 & 52.1 & 118.0 & 173.4 & 130.9 & 148.7 \\
14. Construction & 24.3 & 221.9 & 517.6 & 1937.7 & 1898.7 & 1411.6 & 923.0 \\
15. Trade & 13.5 & 207.1 & 494.4 & 1905.1 & 1824.3 & 1350.0 & 811.6 \\
16. Communications & 7.6 & 242.1 & 269.4 & 329.2 & 930.1 & 696.0 & 685.6 \\
17.Telecommunications & 19.7 & 16.4 & 24.7 & 64.7 & 88.4 & 72.3 & 86.1 \\
18. Financial Business & 28.8 & 33.1 & 78.9 & 65.5 & 166.1 & 85.7 & 144.1 \\
19. Social and other Services & 798.0 & 949.4 & 1524.0 & 3521.0 & 5139.6 & 3859.1 & 3850.8 \\
20. Others & & & & & & \\
$\quad$ Total & & & & & & & \\
\hline \hline
\end{tabular}

Source: Pakistan Economic Survey 2008.

The development of stock market indicates the aggregate level of investment. Total capital assets in the market show the size of the stock market. Pakistan is striving for attracting FDI in order to achieve the country's macroeconomic objectives. FDI has emerged as an important source of capital in Pakistan. Pakistan managed to get US\$3.6 billion worth of foreign investment during 2008. The overall foreign investment in Pakistan is comprised of two components - FDI and portfolio investment (i.e. investment in equity market). US, UK, Netherlands, China and UAE are the major sources of foreign private investments in Pakistan.

FDI stood at US\$3038 million during July-March (2007-08) against US\$3859.1 million in the same period during 2007 showing a decline of $0.2 \%$. Three sectors namely; communication, financial business and oil and gas explorations account for $67 \%$ of FDI inflows in the country (Table 2). The amount of reinvested earning has been increased over the last four years indicating the confidence of the existing foreign investors on the future prospects of Pakistan's economy. 


\section{DATA AND METHODOLOGY}

The following equation ${ }^{\mathrm{a}}$ is estimated to examine the impact of FDI on stock market development:

$$
\ln M C_{t}=\alpha_{1}+\alpha_{2} \ln F D I_{t}+\alpha_{3} \ln G N P C_{t}+\alpha_{4} \ln S A V_{t}+\alpha_{5} I N F_{t}+\mu_{t}
$$

where $M C=$ market capitalization as share of GDP as proxy for stock market development, $\mathrm{FDI}=$ foreign direct investment as share of GDP, GNPC = GNP per capita as proxy for economic growth, SAV = domestic savings as share of GDP, INF = inflation rate and $\mu_{t}$ is the error term. All variables are transformed into the natural logarithm form except INF'.

We obtain the annual data from different sources with sample period ranges from 1971 to 2006. GNP per capita and FDI are collected from World Development Indicators (WDI, 2007). We get the domestic savings rate from Economic Survey of Pakistan (2007) and market capitalization from Statistical Bulletins of State Bank of Pakistan. International Financial Statistics provides us the inflation rate.

Justification of variables taken in the model is discussed below:

Market capitalization: Stock market development is usually measured by stock market's size, liquidity, volatility, concentration, and integration with world capital markets. Market capitalization is defined as the total market value of all listed shares. Following Adam and Tweneboah (2009), market capitalization as a proportion of GDP is used as a proxy for stock market development. Garcia and Liu (1999) argued that this measure is less arbitrary than other measures of stock market development.

FDI: The relationship between FDI and stock market development has been widely discussed in the literature (Errunza, 1983; Gracia and Liu, 1999; Yartey and Adajasi, 2007 and Adam and Tweneboah, 2009). FDI may either complement or substitute the development of stock market.

GNP per capita: Numerous studies have suggested that economic growth and stock market development are positively related to each other (Spears, 1991; Atje and Jovanovic, 1993; Garcia and Liu, 1999; Luintel and Khan, 1999). In this paper, it is hypothesized that economic growth promotes stock market development.

Domestic savings: Higher rate of domestic savings in an economy accelerates stock market's activities. Garcia and Liu (1999) found a strong statistical positive relationship between stock market development and savings. This infers that larger savings boost higher amount of capital flows through stock markets.

Inflation: Garcia and Liu (1990) and Naceur, Samir, Omran (2007) used inflation rate as a proxy for macroeconomic stability in their empirical studies and found a positive relationship between the economic stability and stock market development. Shahbaz (2007) also supported the positive relationship between nominal stock returns and inflation in Pakistan.

\footnotetext{
a Log-linear specification performs betters compare to the simple linear model. Ehrlich (1977) and Layson (1983) argued on theoretical and empirical grounds that log-linear specification makes results more favorable.

${ }^{\mathrm{b}}$ Inflation is used rather than price index because we get the data directly from International Financial Statistics. Since INF is in the format of growth rate, it is no need to be transformed into natural logarithm.
} 


\section{A. ARDL Approach for Cointegration}

Pesaran, Shin, Smith (2001) established an advanced approach to examine cointegration among variables. This approach is termed as Autoregressive Distributive Lag (ARDL) boundstest. The ARDL model can be applied without investigating the order of integration (Pesaran and Pesaran, 1997). It is well known that most macroeconomic variables are integrated at either I(0) or I(1). Haug (2002) argued that the ARDL approach for cointegration presents better results for small sample data compare to other techniques for cointegration such as Engle and Granger (1987), Johansen (1991) and Philips and Hansen (1990).

Furthermore, the unrestricted error correction model (UECM) seems to take satisfactory lags that captures the data generating process in a general-to-specific framework of specification (Laurenceson and Chai, 2003). However, Pesaran and Shin (1999) contented that "appropriate modification of the orders of the ARDLmodel is sufficient to simultaneously correct for residual serial correlation and the problem of endogenous variables". The UECM is being constructed to examine the long-run and short-run relationships among the variables:

$$
\begin{aligned}
\Delta \ln M C_{t} & =\alpha_{0}+\alpha_{1} T+\alpha_{M C} \ln M C_{t-1}+\alpha_{F D I} \ln F D I_{t-1}+\alpha_{G N P C} \ln G N P C_{t-1}+\alpha_{S A V} \ln S A V_{t-1} \\
& +\alpha_{I N F} I N F_{t-1}+\sum_{i=1}^{m} \beta_{i} \Delta \ln M C_{t-i}+\sum_{j=0}^{n} \delta_{j} \Delta \ln F D I_{t-j}+\sum_{k=0}^{o} \phi_{k} \Delta \ln G N P C_{t-k} \\
& +\sum_{l=0}^{p} \varphi_{l} \Delta \ln S A V_{t-l}+\sum_{m=0}^{q} \gamma_{m} \Delta I N F_{t-m}+\mu_{t}
\end{aligned}
$$

where $\mathrm{T}$ is trend ${ }^{\mathrm{c}}$.

Equation (2) presents two segments of results. The first part indicates the long association between the variables such as $\alpha_{M C}, \alpha_{F D I}, \alpha_{G N P C}, \alpha_{S A V}, \alpha_{I N F}$ while $\beta, \delta, \phi, \varphi$ and $\gamma$ explore the short-run dynamic relationships. On the other hand, $\mu_{t}$ refers to the error term and $m, n, o$, $p$ and $q$ are the number of lags for the difference terms of the variables. The hypothesis of no cointegration $\left(\alpha_{M C}=\alpha_{F D I}=\alpha_{G N P C}=\alpha_{S A V}=\alpha_{I N F}=0\right)$ is examined. The decision about cointegration is based on the computed F-statistic. The critical bounds to compare with the F-statistic have been tabulated by Pesaran, Shin, Smith (2001) and later by Narayan (2005) for small samples. The upper critical bound (UCB) is based on the assumption that all variables are integrated at $\mathrm{I}(1)$ and the lower critical bounds (LCB) variables should be integrated at level. If UCB is lower than the F-statistic, then the decision is in favor of cointegration among the variables. This indicates the existence of long run relationship among the variables. If the $F$ statistic is less than LCB, then it favors no cointegration among the variables. The decision about cointegration will be inconclusive if the F-statistic falls between UCB and LCB. In such situation, we will have to rely on the finding of lagged error correction term (ECT) for cointegration to investigate the long run relationship.

\footnotetext{
' $T$ is included in the model to capture the trend that appears in all series.
} 
If there is long run relationship among the variables, the short run behavior of variables is investigated by the following ECM:

$$
\begin{aligned}
\Delta \ln M C_{t} & =\delta_{1}+\sum_{i=0}^{m} \delta_{2} \Delta \ln M C_{t-i}+\sum_{j=0}^{n} \delta_{3} \Delta \ln F D I_{t-j}+\sum_{k=0}^{o} \delta_{4} \Delta \ln G N P C_{t-k}+\sum_{l=0}^{p} \delta_{5} \Delta \ln S A V_{t-l} \\
& +\sum_{m=0}^{q} \delta_{6} \Delta I N F_{t-m}+\eta E C M_{t-1}+\mu_{t}
\end{aligned}
$$

where $m, n, o, p$ and $q$ are the lag length of the variables respectively which is selected following AIC criteria. It is documented that if the value of lagged ECM is between 0 and -1 , then adjustment to the dependent variable in current period is the ratio of error in the previous period. In such situation, ECM causes the dependent variable to converge to long span equilibrium due to variations in the independent variables. The goodness of fit for ARDL model is checked through stability tests such as cumulative sum of recursive residuals (CUSUM) and cumulative sum of squares of recursive residuals (CUSUMSQ). Finally, sensitivity analysis is also conducted.

\section{EMPIRICAL RESULTS}

ARDL has the advantage of avoiding the classification of variable into $I(0)$ or $I(1)$ as there is no need for unit root pre-testing. According to Sezgin and Yildirim, (2002), in the presence of $I(2)$ variables, the computed F-statistics provided by Pesaran, Shin, Smith (2001) become invalid because bounds test is based on the assumption that the variables are $I(0)$ or $I(1)$ or mutually cointegrated. Therefore, the implementation of unit root test in the ARDL procedure might still be necessary to ensure that none of the variable is integrated at order 2 or beyond. For this purpose, Augmented Dickey Fuller (ADF) unit-root test has been employed to find out the order of integration for all series in this study. The results in Table 4 show that INF is I(0) while MC, FDI, GNPC and SAV are I(1). This dissimilarity in the order of integration of the variables leads us to support the implementation of ARDL bounds testing approach for cointegration ${ }^{d}$.

TABLE 4-UNIT ROOT RESULTS

\begin{tabular}{lcccc}
\hline \hline \multirow{2}{*}{ Variables } & Level & \multicolumn{2}{c}{ First Difference } \\
& Intercept and trend & Prob-value & Intercept and trend & Prob-value \\
\hline \hline InMC & -2.8223 & 0.2001 & $-5.0297^{*}$ & 0.0015 \\
InFDI & -3.0809 & 0.1269 & $-7.4962^{*}$ & 0.0000 \\
InGNPC & -1.3699 & 0.8506 & $-6.0279^{*}$ & 0.0001 \\
INF & $-3.6526^{* *}$ & 0.0400 & $-4.8539^{*}$ & 0.0023 \\
InSAV & -3.1266 & 0.1170 & $-5.2366^{*}$ & 0.0009 \\
\hline \hline
\end{tabular}

Note: ${ }^{*}$ and ${ }^{* *}$ represent significant at $1 \%$ and $5 \%$ respectively.

Source: authors' calculation

${ }^{\mathrm{d}}$ We use EViews 7.1 for the empirical analysis.

24 THE IMPACT OF FOREIGN DIRECT INVESTMENT ON STOCK MARKEET DEVELOPMENT : EVIDENCE FROM PAKISTAN 
TABLE 5-LAG LENGTH SELECTION AND F-STATISTICS

\begin{tabular}{lccc}
\hline \hline Order of lags & Akaike Information Criteria & Schwartz Bayesian Criteria & F-Statistics \\
\hline \hline 0 & 5.9335 & 6.1580 & 3.4517 \\
1 & 2.6781 & 4.0249 & $4.8281^{* * *}$ \\
\hline \hline
\end{tabular}

Note: ${ }^{* * *}$ represents significant at the $10 \%$ level.

Source: authors' calculation

Now we turn to the two-step ARDL cointegration procedure. In the first stage, we use an UECM version of the ARDL model for equation 2, to obtain an appropriate lag order of the variables by means of Akaike Information Criterion (AIC), which is 1 based on the minimum value of AIC as shown in Table 5. The result of the bounds testing approach for cointegration posit that the calculated F-statistic is 4.83 which is higher than the upper level of bounds critical value of 4.78 at the 10 percent level of significance. The critical value is referred from Pesaran, Shin, Smith (2001). This implies that there is a cointegration relationship among the variables. Long-run elasticities are reported in Table 6 through the ARDL estimation.

TABLE 6-LONG-RUN ELASTICITIES

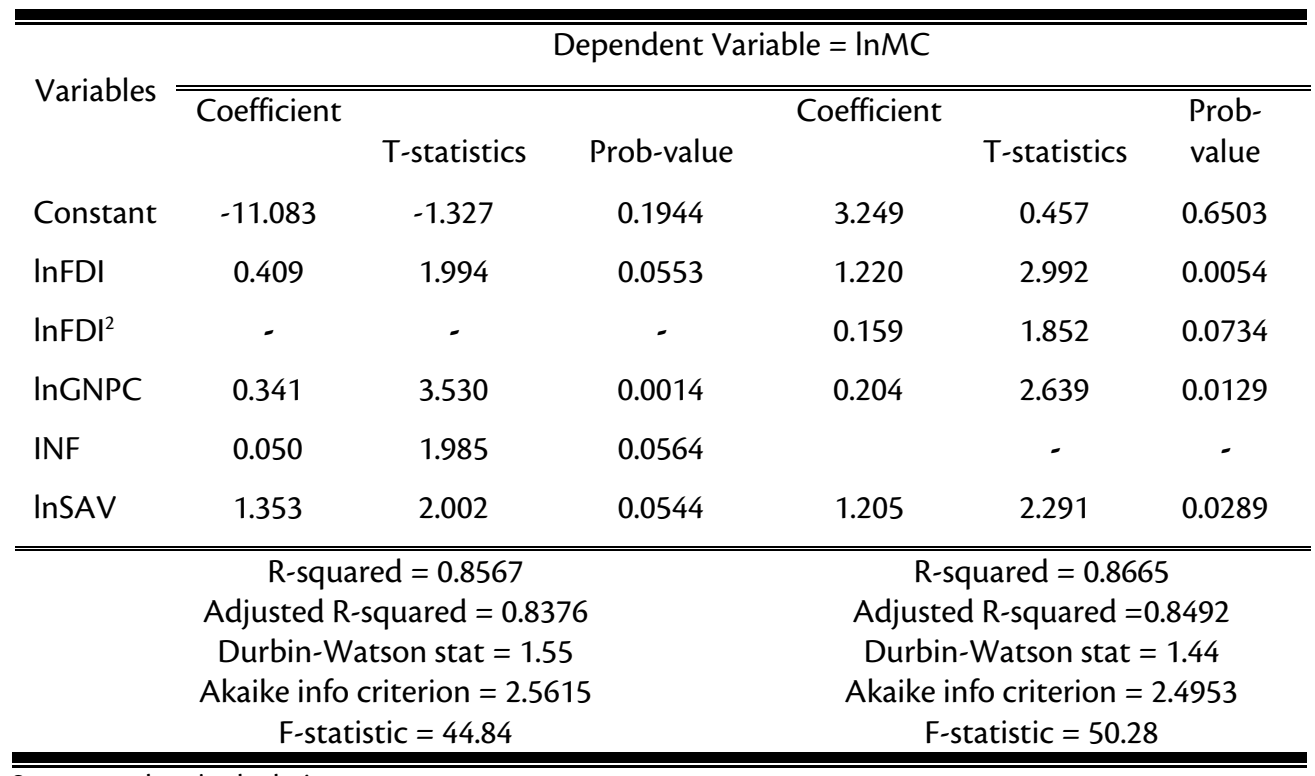

Source: authors' calculation

It is documented that one percent increase in FDI is associated with a 0.4 percent increase in market capitalization. This confirms that the relationship between FDI and stock market development is complementary. Economic growth is linked positively with the development of stock markets in Pakistan. The impact of inflation on stock market development is positive but minimal. The positive association between inflation and stock market development supports that Pakistan's stock markets are hedge against inflation. In other words, stock market is an alternative place for investors to hedge their risk against inflation in Pakistan. Domestic savings seem to improve the efficiency of stock market in the country. It is concluded that 1 percent increase in domestic savings increases growth of stock markets by 1.35 percent. 
The non-linear impact of FDI is also checked by including squared term of LFDI in the modele. The result (Table 6 right hand panel) again confirms that the non-linear impact of FDI on stock market is positive and significant. This finding supports the argument of Claessens, Daniela, Schmukler (2001) that FDI is playing a complementary role in stimulating the stock market development.

Table 7 reports the results of short-run dynamics of variables estimated from ECM. The existence of ECM among the cointegrated variables implies that change in the dependent variable is a function of both the levels of disequilibrium in the cointegration relationship and the changes in the other explanatory variables. This tells us that any deviation from the long-run equilibrium will feed back on the change in the dependent variable in order to force the movement towards the long-run equilibrium (Masih and Masih, 2002). The coefficient of lagged ECM shows speed of adjustment from short run to long span of time and it should have a statistically significant estimate with negative sign. According to Bannerjee, Dolado, Mestre (1998) "a highly significant lagged ECM is further proof of the existence of stable long-run relationship". The coefficient of $E C M_{t-1}$ is -0.709 implies that deviation from the long-term economic growth is corrected by 70.9 percent over each year.

\section{TABLE 7 - SHORT RUN DYNAMICS}

\begin{tabular}{|c|c|c|c|}
\hline \multicolumn{4}{|c|}{ Dependent Variable: $\Delta \ln M C$} \\
\hline Variable & |Coefficient & $\mid \mathrm{T}$-Statistic $\mid$ & Prob-value \\
\hline Constant & 0.104 & 0.949 & 0.3504 \\
\hline$\Delta \operatorname{lnFDI}$ & 0.210 & 1.652 & 0.1097 \\
\hline$\Delta \mathrm{INF}$ & -0.011 & -0.413 & 0.6830 \\
\hline$\triangle \mathrm{InGNPC}$ & 2.076 & 2.686 & 0.0120 \\
\hline$\triangle \mathrm{InSAV}$ & -0.935 & -1.282 & 0.2104 \\
\hline $\mathrm{ECM}_{\mathrm{t}-1}$ & -0.709 & -4.667 & 0.0001 \\
\hline $\begin{array}{r}\text { Serial C } \\
A R \\
\text { Heterosk }\end{array}$ & $\begin{array}{l}\text { R-square } \\
\text { djusted R-sq } \\
\text { kaike info cr } \\
\text { F-statisti } \\
\text { Prob(F-stati } \\
\text { urbin-Wats } \\
\text { Sensitivit } \\
\text { orrelation T } \\
\text { RCH Test = } \\
\text { kedasticity T }\end{array}$ & $\begin{array}{l}\mathrm{d}=0.4761 \\
\text { uared }=0.3 \\
\text { iterion }=1.9 \\
\mathrm{ic}=5.089 \\
\text { istic })=0.00 \\
\text { on stat }=1.9 \\
\text { y Analysis } \\
\text { est }=1.9079 \\
0.6802(0.51 \\
\text { est }=1.796\end{array}$ & $\begin{array}{l}7(0.1827) \\
146) \\
7(0.4210)\end{array}$ \\
\hline
\end{tabular}

Source: authors' calculation

\footnotetext{
e INF is insignificant at $10 \%$ level of significance based on t-statistics; hence, we exclude INF from the model. 
In the short-run, FDI is linked positively to the stock market development. The positive sign between these two variables again shows that FDI and stock market development nexus is complementary in short span of time. Increase in inflation and domestic saving is associated negatively with stock market development but the relationships are insignificant. This implies that inflation and domestic saving may take time to show their impact on stock market development. GNP per capita and stock market development are correlated positively and GNP per capita is showing dominating impact on stock market development in short-run.

\section{SENSITIVITY ANALYSIS}

To check for the serial correlation, autoregressive conditional heteroskedasticity (ARCH) and White heteroskedasticity for the model related diagnostic tests have been conducted. Table 7reports that the model passes the diagnostic tests. No evidence of autocorrelation, heteroskedasticity and ARCHis found in the model. Finally, the stability of the long-run coefficients together with the short-run dynamics are checked by the CUSUM and CUSUMSQ with recursive residual as shown in Figures 1 and 2.Bahmani-Oskooee and Nasir (2004) stated that null hypothesis that the regression equation is correctly specified cannot be rejected if the plot of these statistics remains within the critical bounds of the $5 \%$ significance level. Figure 1 and Figure 2 show that the plots of both the CUSUM and the CUSUMSQ are within the boundaries. These plots confirm the stability of the long-run coefficients of regressors that affect the stock market development.

\section{FIGURE 1. PLOT OF CUMULATIVE SUM OF RECURSIVE RESIDUALS}

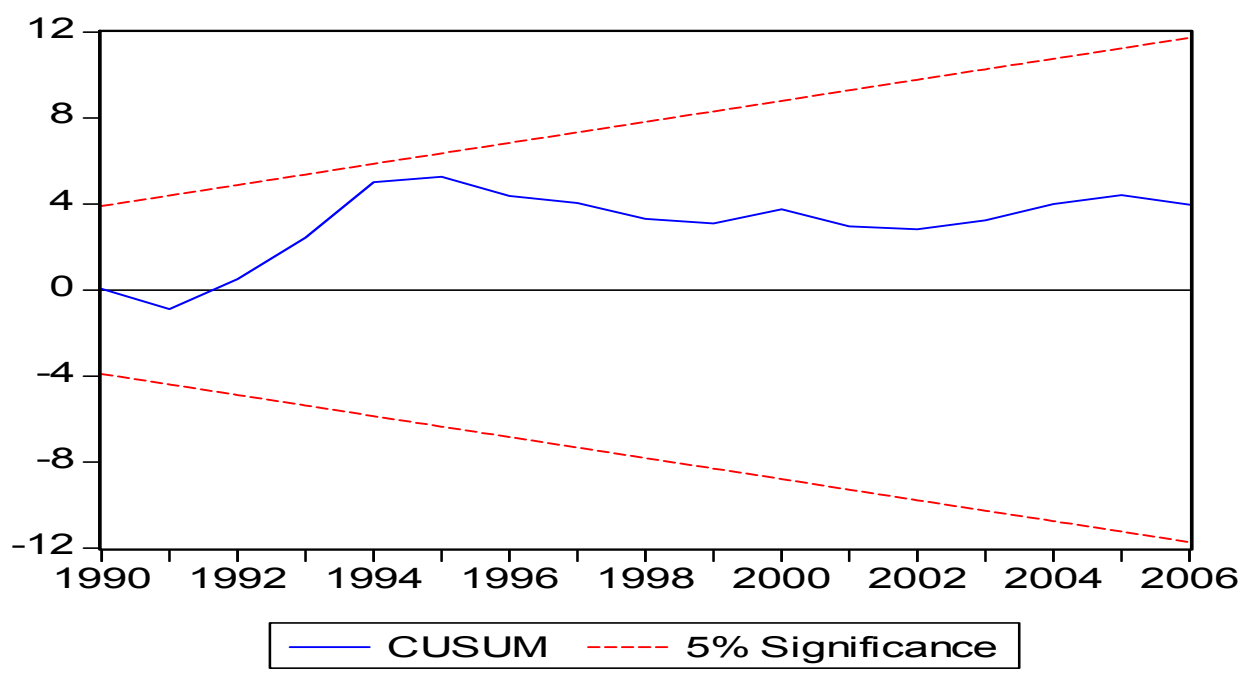

Note: The dotted lines represent critical bounds at $5 \%$ significance level. Source: Authors' estimation. 


\section{FIGURE2. PLOT OF CUMULATIVE SUM OF SQUARES OF RECURSIVE RESIDUALS}

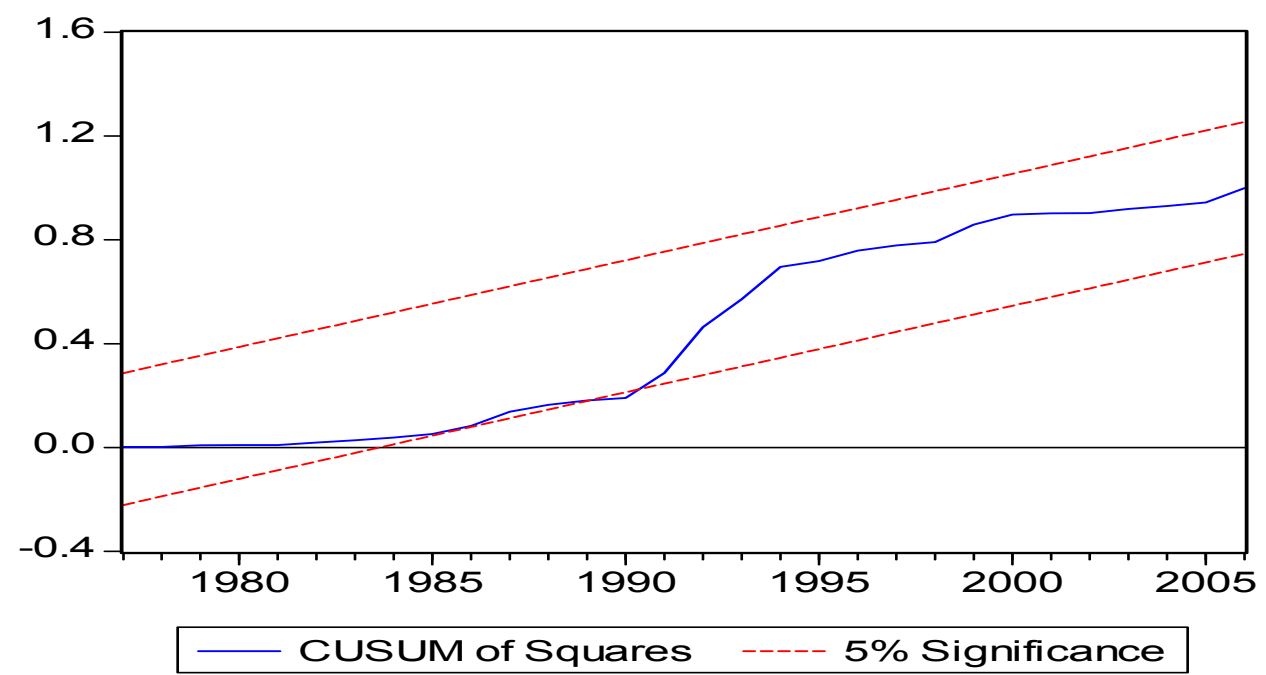

Note: The dotted lines represent critical bounds at $5 \%$ significance level.

Source: Authors' estimation.

\section{CONCLUSION AND POLICY IMPLICATIONS}

This paper identifies macroeconomic variables with particular emphasis on FDI that affect stock market development in Pakistan. The empirical results indicate a significant positive relationship between FDI and market capitalization in the long-run. This infers the complementary role of FDI to the stock market development in Pakistan. Savings also show a strong positive relationship with the stock market development in the long-run. Impact of GNP implies that economic growth is imperative for the development of stock market in Pakistan. In the short run, FDI and economic growth have positive impact on stock market development. Although inflation and domestic savings are inversely linked with stock market development but they are statistically insignificant.

Stock market is a key element of the modern and market-based economic system because it serves as the main channel to collect funds from depositors to borrowers. As FDI is complement to the development of stock market, the Pakistan government should attract FDI by taking various steps such as 1) assurance of political stability in the country 2) adequate provision of infrastructure 3) minimize thevolatility of foreign exchange and the rate of interest through appropriate and effective monetary policy 4 ) incentives such as tax exemption, improve the infrastructure in the country etc.

Furthermore, the government should take some appropriate steps to improve the efficiency and transparency of the primary market. It will not only strengthen the government securities in the stock market but also improve efficiency and development of secondary market. Government should encourage FDI in stock market as well to enhance competition, creation of new job opportunities by transferring new technology and skill. 


\section{REFERENCES}

Adam, A. M. and Tweneboah, G. "Foreign Direct Investment and Stock Market Development: Ghana's Evidence."International Research Journal of Finance and Economics, 26(2009): 179185.

Atje, R. and Jovanovic, B. "Stock Markets and Development."European Economic Review 37, (1993): 632-640.

Bannerjee, A., Dolado, J. and Mestre, R. "Error Correction Mechanism Tests for Co-integration In Single Equation Framework."Journal of Time Series Analysis 19, (1998): 267-83.

Boyd, J. H. and Smith, B. D. "Intermediation and the Equilibrium Allocation of Investment Capital: Implications for Economic Development." Journal of Monetary Economics30, (1992): 409-432.

Brecher, R. "Second-Best Policy for International Trade and Investment."Journal of International Economics 14, (1983): 313-320.

Brecher, R. and Diaz-Alejandro, C. "Tariffs, Foreign Capital and Immiserizing Growth." Journal of International Economics 7, (1977): 317-322.

Carkovic, M. and Levine, R. "Does Foreign Direct Investment Accelerate Economic Growth? Department of Finance."Working paper, University of Minnesota, 2002.

Chousa, J. P., Krishna, C. and Tamazian , A. "Does Growth \& Quality of Capital Markets Drive Foreign Capital?,William Davidson Institute ." Working paper Series, University of Michigan, Stephen M. Ross Business School. 911 No., 2008.

Claessens, S., Daniela K. L. and Schmukler, S. L."The Future of Stock Exchanges in Emerging Markets- Evolution and Prospects." Brookings-Wharton Papers on Financial Services 2002, The Brookings Institution, Washington, D.C., 167-212, 2002.

Demirgue-Kunt, A. and Levine, R. "Stock Market Corporate Finance and Economic Growth: An Overview." The World Bank Review10, (1996): 223-239.

Economic Survey of Pakistan, “Ministry of Finance”, Islamabad, Pakistan, 2008.

Ehrlich, I. "The Deterrent Effects of Capital Punishment Reply."American Economic Review67, (1977): 452-58.

Engle, R. F. and Granger, C. W. J. "Cointegration and Error Correction Representation: Estimation and Testing." Econometrica 55, (1987): 251-276.

Errunza, V. R. "Emerging Markets - A New Opportunity for Improving Global Portfolio Performance." Financial Analysts Journal 39, (1983): 51-58.

Fritz, F. C., Desai, M. A. and Hines Jr., J. R. "Foreign Direct Investment and the Domestic Capital Stock."American Economic Review Papers and Proceedings92, (2005): 33-38.

Garcia, V. F. and Liu, L. "Microeconomic Determinants of Stock Market Development." Journal of Applied Economics2, (1999): 29-59.

Haug, A. "Temporal Aggregation and the Power of Cointegration Tests: A Monte Carlo Study." Oxford Bulletin of Economics and Statistics64(2002): 399-412. 
Husain, F. and Mahmood, T. "The Stock Market and the Economy in Pakistan." Pakistan Development Review 40, (2001): 107-114.

Johansen, S. "Estimation and Hypothesis Testing of Cointegrating Vectors in Gaussian Vector Autoregressive Models."Econometrica 59, (1991): 1551-1580.

Johnson, A. "The Effects of FDI Inflows on Host Country Economic Growth" Working paper No. 58, Centre for Excellence for Science and Innovation Studies, Royal Institute of Technology, 2005.

Khan, M. N. and Zaman, S "Impact of Macroeconomic Variables on Stock Prices: Empirical Evidence from Karachi Stock Exchange, Pakistan." Business, Economics, Financial Sciences, and ManagementAdvances in Intelligent and Soft Computing 143, (2012): 227-233.

Krkoska, L. "Foreign Direct Investment Financing of Capital Formation in Central and Eastern Europe."European Bank for Reconstruction and Development (EBRD), December 2001, Working Paper No. 67., 2001.

Laurenceson, J. and Chai, J. C. H. "Financial Reform and Economic Development in China." Cheltenham, UK, Edward Elgar, 2003.

Layson, S. "Homicide and Deterrence: Another View of the Canadian Time Series Evidence."Canadian Journal of Economics16, (1983): 52-73.

Levine, R. and Zervos, S. "Stock Markets, Banks, and Economic Growth."American Economic Review 88, (1998): 537-558.

Luintel, K. B. and Khan, H. "A Quantitative Reassessment of the Finance-Growth Nexus: Evidence from a Multivariate VAR."Journal of Development Economics 60, (1999): 381-405.

Masih, A. M. M. and Masih, R. "Propagative Causal Price Transmission among International Stock Markets: Evidence from the Pre- and Post Globalization Period."Global Finance Journal 13, (2002): 63-91.

Naceur S. B., Samir, G. and Omran, M. "The Determinants of Stock Market Development in the Middle-Eastern and North African Region." Managerial Finance 7, (2007): 477-489.

Narayan, P. K. "The Savings and Investment Nexus for China: Evidence from Co-integration Tests."Applied Economics 37, (2005): 1979-1990.

Nishat, M. and Shaheen, R. "Macroeconomic Factors and Pakistani Equity Market." The Pakistan Development Review 4, (2004): 619-637.

Pesaran, M. H. and Pesaran, B.Working with Microfit 4.0: Interactive Econometric Analysis, Oxford: Oxford University Press, 1997.

Pesaran, M. H., Shin, Y. and Smith, R. J. "Bounds Testing Approaches to the Analysis of Level Relationships."Journal of Applied Econometrics 16, (2001): 289-326.

Pesaran, M.H. and Shin, Y. "An Autoregressive Distributed-led Modeling Approach to Cointegration Analysis." In Econometrics and Economic Theory in the 20th Century. The Ragnar Frisch Centennial Symposium, ed. Steinar Strom. Cambridge: Cambridge University Press, 1999.

Phillips, P. C. B. and Hansen, B. E. "Statistical Inference in Instrumental Variables Regression with I(1) Processes." Review of Economic Studies57, (1990): 99-125. 
Rahman, M. M. and Salahuddin, M. "The Determinants of Economic Growth in Pakistan: Does Stock Market Development Play a Major Role?" 38th Australian Conference of Economists (ACE 2009), 28-30 Sept 2009, Adelaide, Australia, 2009.

Rashid, A. "Macroeconomic Variables and Stock Markets Performance: Testing for Dynamic Linkages with a Known Structural Break."Savings and Development32, (2008): 77-102.

Raza, A., Iqbal, N., Ahmad, Z., Ahmad, M. and Ahmad, T. "The Role of FDI on Stock Market Development: The Case of Pakistan."Journal of Economics and Behavioral Studies 4, (2012): 26-33.

Romer, P. "Idea Gaps and Object Gaps in Economic Development."Journal of Monetary Economics 32, (1993): 543-573.

Sarkar, P. "Stock Market Development and Capital Accumulation: What the Time Series Evidence Shows" Paper presented at AISSEC Conference, University of Parma, Italy (21-23) January 2007, 2007.

Sezgin, S. and Yildirm, J. "The Demand for Turkish Defence Expenditure." Defence and Peace Economics13, (2002): 121-128.

Shahbaz, M. "Stock Market Returns and Inflation: An ARDL Econometeric Investigation Utilizing Pakistani Data." Pakistan Economic and Social Review 45, (2007): 89-105.

Shahbaz, M., Ahmed, N. and Ali, L. "Stock Market Development and economic Growth: ARDL Causality in Pakistan." International Research Journal of Finance and Economics 14, (2008): 184-194.

Singh, A. "Financial Liberalization, Stock Markets, and Economic Development."Economic Journal 107, (1997): 771-782.

Sohail, N. and Hussain, Z. "The Macroeconomic Variables and Stock Returns in Pakistan: The Case of KSE 100 Index." International Research Journal of Finance and Economics 80, (2011): 66-74.

Spears, A. "Financial Development and Economic Growth-Causality Tests."Atlantic Economic Journal 19, (1991): 66-74.

Yartey, C. A. and Adjasi, C. K. "Stock Market Development in Sub-Sharan Africa: Critical Issues and Challenges." IMF Working Paper 07/209. Washington DC: International Monetary Fund., 2007.

Yatrey, C. A. "The Determinants of Stock Market Development in Emerging Economies: Is South Africa Different."IMF Working Paper 08/38, Washington DC: International Monetary Fund., 2008. 


\section{UTJECAJ IZRAVNIH STRANIH ULAGANJA NA RAZVOJ TRŽIŠTA DIONICA: DOKAZ IZ PAKISTANA}

Sažetak: Zemlje u razvoju doživljavaju promjene u sastavu tokova kapitala u svojim gospodarstvima radi ekspanzije i integracije svjetskog tržišta kapitala. Ovaj rad istražuje utjecaj izravnih stranih ulaganja na razvoj tržišta dionica u Pakistanu. Ključni interes se vrti oko komplementarne ili zamjenske uloge izravnih stranih ulaganja u razvoju tržišta dionica. Za analizu su korišteni ARDL granični test za kointegraciju i ECM. Rezultati podupiru tezu o komplementarnoj ulozi izravnih stranih ulaganja u razvoju tržišta dionica u Pakistanu. Osim toga, domaća štednja, prihodi i inflacija su ostale makroekonomske varijable koje utječu na razvoj tržišta dionica u Pakistanu.

Ključne riječi: Razvoj tržišta dionica, izravna strana ulaganja, Pakistan, komplementarna uloga, kointegracija 